\title{
How to Use Historical Approach to Teach Nature of Science in Chemistry Education?
}

\section{Tolvanen, Simo}

2014-08

Tolvanen , S , Jansson , J , Vesterinen , V-M \& Aksela , M 2014 , ' How to Use Historical Approach to Teach Nature of Science in Chemistry Education? ' , Science \& Education, vol. 23 , no. 8 , pp. 1605-1636 . https://doi.org/10.1007/s11191-013-9646-x

http://hdl.handle.net/10138/154417

https://doi.org/10.1007/s11191-013-9646-x

submittedVersion

Downloaded from Helda, University of Helsinki institutional repository.

This is an electronic reprint of the original article.

This reprint may differ from the original in pagination and typographic detail.

Please cite the original version. 


\title{
How to Use Historical Approach to Teach Nature of Science in Chemistry Education?
}

\author{
SIMO TOLVANEN, JAN JANSSON, VELI-MATTI VESTERINEN AND MAIJA AKSELA
}

University of Helsinki, Department of Chemistry, PL 55, 00014 Helsingin yliopisto, Finland

Email: simo.a.tolvanen@helsinki.fi

Tel: +35891915066

\begin{abstract}
Successful implementation of historical approach to teach nature of science (NOS) requires suitable curriculum material. Several research and development projects have produced lesson plans for science teachers. 25 lesson plans from four different projects involved in creating curriculum material utilizing historical approach in chemistry education were analyzed to describe NOS content included as well as the historical experiments and narratives used. Based on the results of descriptive content analysis of existing curriculum materials, several suggestions on the successful design of lesson plans utilizing historical approach are made. To increase the coherence and clarity of learning objectives and instruction, each lesson plan should focus on the limited amount of specific NOS issues instead of several overtly general NOS aspects. To support explicit classroom discussion on the selected NOS issues, historical narratives used in the lesson plans should illustrate these issues. The lesson plans should also include instructions on how to facilitate classroom discussion, such as questions for students to discuss and reflect. Recommendations are also made concerning the appropriate use of historical experiments and narrative elements such as viewpoint characters and conflicts.
\end{abstract}

Keywords: Chemistry Education, Nature of Science, Narrative, History of Science, History of Chemistry 


\section{Introduction}

This study focuses on the use of historical approach in secondary school chemistry education, and especially on using history as a context to teach about nature of science (NOS). NOS is knowledge about characteristics of scientific knowledge and practice. As a central element of scientific literacy understanding, it is widely considered as one of key aims of science education (see e.g. Vesterinen et al., in press). However, for many science teachers, successful teaching of NOS is demanding. Science teachers often do not necessarily have sufficient understanding of NOS, and even having such understanding does not guarantee students' learning of NOS (see Lederman 2007). In addition to sufficient understanding of NOS, teachers also need to have suitable pedagogical skills and content knowledge to teach NOS and they need to appreciate NOS as a learning objective (Lederman 1999, Vesterinen \& Aksela 2012).

Successful implementation of historical approach requires suitable curriculum material. Textbooks already include historical content (see e.g. Niaz \& Rodríguez 2001), but this content often offers distorted information about NOS (Niaz 2010). Although designing NOSrelated curriculum material is an effective method for training teachers to teach NOS (see Lederman et. al 2012, Lin \& Chen 2002, Vesterinen \& Aksela 2012), it would be unrealistic to expect each science teacher to create all curriculum material he or she needs for using historical approach. Currently teachers see the lack of suitable curriculum material as one of the major obstacles for implementing historical approach (Höttecke \& Silva 2011, Höttecke et al. 2012).

There have been number of research and development projects that have produced research based curriculum materials for using historical approach to teach nature of science (see e.g. Clough 2009; Höttecke \& Riess 2009). The goal of this study is to describe the characteristics of the currently available research based lesson plans for using historical approach to teach NOS in chemistry lessons. Description of the common and unique characteristics of the currently available curricula material contributes to our understanding about the elements one has to take into consideration in creating curricula material that utilizes historical approach.

Three research questions guiding the analysis of the lesson plans were:

1. What NOS content is included in the lesson plans?

2. How historical experiments are used to teach NOS?

3. How historical narratives are used in the lesson plans?

To answer these questions, previous literature on historical approach is studied together with available material. In Section 2, different teaching models suggested for historical approach in the literature are studied. The use of historical narratives and their role in historical approach is discussed. In Section 3, the focus is narrowed on chemistry education at secondary level. In Subsection 3.1 four sources for chemistry lesson plans that use historical approach are described. In Subsection 3.2 the method of analyzing the NOS content, historical experiments and historical narratives in the chemistry lesson is described. Section 4 
presents the results of the analysis of the lesson plans and three examples of different uses of historical approach. In Section 5, recommendations for the focus of future projects supporting implementation of historical approach in chemistry education are presented.

\section{Historical Approach in Science Education}

Using historical approach to teach both NOS and science is seen necessary because of teachers' attitudes and requirements of curriculum (e.g. Höttecke \& Silva 2011, Monk \& Osborne 1997). However, merely including history of science content into teaching does not support learning NOS content (Abd-El-Khalick \& Lederman 2000a). For succesfull learning of NOS content, the discussion on the NOS issues to be learned about should be explicit and reflective (Abd-El-Khalick \& Lederman 2000b, Rudge \& Howe 2009).

Historical approach is used to support teaching science content or inquiry skills. Historical concepts can be described in a way that allows students to draw similarities between their own ideas and those held by the past scientists (Monk \& Osborne 1997). Discussing historical conceptions similar to students' ideas allows students to both see the value of their own conceptions and discuss these conceptions without feeling personally criticized (Rudge \& Howe 2009). However, the change of historical concepts and students' conceptual change should not be seen as identical:

There are some very important differences between children's naïve thinking of the 21 st Century, as they struggle to learn existing science, and the earlier speculations of scientists as they struggled to create that science, largely due to very significant differences in social, cultural and intellectual contexts. (Hodson 2008, p. 151)

Following subsection presents description of different teaching models for using historical approach presented in literature. The discussion of the following three subsections focuses on teaching NOS, using historical experiments, and structuring historical narratives suitable for science education.

\subsection{Models for Using Historical Approach to Teach Nature of Science}

Stinner and colleagues (2003) list six different ways of utilizing historical approach in science education: confrontations, dialogues, drama, vignettes, case studies and thematic narratives. Confrontations are conflicts between two or more theories, while dialogues are conflicts between persons (Stinner et al. 2003). Discussing historical controversies allows students to understand that science includes conflicts (Niaz 2009) and that these conflicts can be used to show students how science evolves through debate (Garritz 2013, Niaz 2010). Drama can be used as writing plays and acting to discuss interactions between science and society (Stinner et al. 2003), or included into case studies as role-playing activities (Höttecke \& Riess 2009, Höttecke et al. 2012).

Vignettes are short descriptions of historical events. Vignettes focus on a single NOS aspect (Wandersee 1990, cited in Wandersee \& Baudoin Griffard 2002) and allow students to 
discuss and solve confrontation presented inside (Wandersee \& Baudoin Griffard 2002). Afterwards, the NOS topic is named and connected to both the relevant science content and societal issues (Wandersee \& Baudoin Griffard 2002). Vignettes may be used as authentic and interesting examples when discussing NOS (McComas 2008). Monk and Osborne (1997) see historical approach suitable for teaching epistemology and cultural context of science, in addition to scientific concepts. In their model, historical vignettes are used to present historical explanations of scientific phenomena. This presentation describes also the social context where past scientist worked. Beside historical definitions of science concepts, the textbook explanations are also presented. This allows students to compare their own preconceptions with other explanations. NOS content is discussed implicitly, not explicitly. (Monk \& Osborne 1997) Rudge and Howe (2009) criticize the way model suggested by Monk and Osborne connects the historical context to neither students' preconceptions nor modern explanation of phenomenon. They suggest that the historical definitions of scientific concepts should be both similar to the students' preconceptions and the modern definitions students are supposed to learn. According to them, the choice of historical material presented should also be guided by NOS learning objectives and the discussion of NOS topics should be explicit and reflective.

During past decade, the research has focused on the use of case studies. Reading vignettes is seen as passive alternative for approaches where students can actively develop their own conceptions with the help of history (Rudge \& Howe 2009). In a case study, history is used as an overall context for the lesson. Case studies are defined as "historical contexts with one unifying idea" (Stinner et al. 2003, p. 620) and others add to this description the emphasis on the active role of students (Höttecke \& Riess 2009). When used in historical approach, "case study considers science in a detailed, but exemplary manner in order to highlight general aspects of science, epistemology, scientific content and the NoS" (Höttecke et al. 2012, p. 1235). Case studies allow discussing more complex NOS issues than short vignettes (Allchin 2011a)

Irwin (2000) studied effect of historical case study on student's learning of chemistry and NOS. He taught historical development of atomic theory for 14-year-old students over period of four lessons. A case study expanding over several lessons is similar to thematic narrative, a larger storyline that consist of several small case studies and may be interdisciplinary (Stinner et al. 2003). ${ }^{1}$ Lin and colleagues (2010) used approach where short historical episodes were used to describe several storylines related to the progress of classical genetics. These episodes were inserted into regular biology lessons and discussed alongside with biology content to show the "interdependent and dynamic nature of science" (Lin et al. 2010, p. 2530).

\subsection{Models for Using Historical Experiments to Teach Nature of Science}

\footnotetext{
${ }^{1}$ Similar structure was also suggested by Rudge and Howe (2009), who used research on sickle cell anemia as a context for eight lessons, each lesson discussing different case in the history of said research.
} 
Also historical experiments may be used in historical approach, either by discussing them ${ }^{2}$ or conducting the experiments. Using historical experiments in historical approach may help students to understand processes of science (Allchin 1999). Replicating historical experiments allow students to understand the role of experiments in the history of science and in the production of new knowledge (Höttecke 2000). These replications of historical experiments can be either historical or physical. In historical replication, the experiment is repeated using equipment as authentic as possible. In physical replication, the experiment is repeated using modern equipment (Chang 2011, Höttecke 2000). Extensions of historical experiments use the original experimental setting only as a starting point for students' own inquiry (Chang 2011).

Representations of historical experiments are a form of case study where historical experiments are simulated in a way that is more suitable for school environment than historical replication (Metz \& Stinner 2006). Used together with historical narrative, representations allow students to design experiments, evaluate the results of experimentation and construct scientific explanations and discuss NOS content (Metz \& Stinner 2006).

NOS content can also be taught using complementary historical experiments (see Chang 2011). Complementary experiments are historical experiments related to topics known in the past but later neglected or forgotten. They allow students to participate in authentic inquiry activities, which can support their understanding of NOS. Physical replication of past experiments inconsistent with the textbook science explanations may help students to understand the difference between scientific practice and school science practice. Extending these historical experiments to new directions allow students to take part in authentic inquiry activities.

Building historical context for a lesson requires making decisions between conflicting interests. Decisions of what historical information is presented should be based on students' previous knowledge and science-related and NOS related learning objectives of the lesson (de Mello Forato et al. 2012). Historical context may be built to support the NOS learning objectives (de Mello Forato et al. 2012; Rudge \& Howe 2009) or these learning objectives may rise from the historical case study (Ducheyne 2012, Metz \& Stinner 2003). Omitting historical, scientific or mathematical detail may cause the lesson to give distorted view of some aspect of NOS (de Mello Forato et al. 2012). This distortion is sometimes justified by demands of learning science, and by arguing that distortion is irrelevant for students learning of NOS, when the level of precision is suitable for school science education (Rudge \& Howe, 2009).

\subsection{History of Science Narratives}

Norris and colleagues (2005) have attempted defining narrative through narrative elements included in the story. When discussing history of science, we are forced to tell stories to convey knowledge about the events in question to the audience. These kinds of events easily

\footnotetext{
${ }^{2}$ Ducheyne (2012) describes a case study where the Cavendish experiment is discussed with students without conducting the experiment. Niaz (2010) uses descriptions of historical experiments when teaching with controversies.
} 
include many or all of these narrative elements. We have chronologically related events, a narrator and a receiver of this structured presentation which often has some in-built reasoning and agency of its main characters.

In their summary of experimental research on the use of narratives, Norris and colleagues (2005) conclude that conveying information in the form of narratives is moderately more efficient than conveying it in the form of formal text book text. This may be due to for example easier reading and stories' inherent ability to awaken interest. This narrative effect is one of the reasons teaching NOS through narratives is expected to yield good results.

In the context of science education the content of the story to be told is important. For example de Mello Forato and colleagues (2012) have discussed the level of detail and accuracy needed for educational material. Detailed descriptions are needed to avoid too linear view on how science produces new knowledge and to allow interpreting history of science in its context. On the other hand the limits of teachers' understanding of history of science and the capabilities of the students have to be taken into account. Omitting historical facts from the narrative should always be done after careful examination of the resulting change in the picture the narrative presents.

Use of narratives has been justified also based on the effect on student engagement. For example, Rudge and Howe (2009) promote their explicit and reflective approach to use of history to teach NOS in order to engage students in learning. They propose "instrumental" use of history in which it is desirable for the educator to present only chosen parts of the actual historical events for the best results in learning and student engagement (Rudge and Howe 2009, p. 566).

Since use of narratives is an important part of teaching history of science, some attempts on defining a good narrative and giving instructions to writing one have been made. Norris and colleagues (2005) described several elements of narratives, but concluded that giving a recipe for good storytelling is hard. Klassen (2009) analyses a story using the elements described by Norris and colleagues (2005) and two additional described by Kubli (2001), but admits that the description of the elements does not give a method for writing good stories. As Klassen (2009) points out, academic science is hard pressed in analyzing the use of artistic products in use of science education.

Stinner and colleagues (2003) have produced a synthesis of guidelines for designing historical case studies about choosing a "story line". Story line should for example start from a context from which the problems arise easily and include interesting controversies. Even these guidelines still leave a lot of room to artistic choice and creativity.

\section{Methods and Materials}

Lesson plans published in four different sources were analyzed. Subsection 3.1 describes the material analyzed and Subsection 3.2 describes the method of analysis. Even if called lesson plans in this study, the curriculum material analyzed in this study varied in structure and in detail. Some were actual lesson plans, meaning that they could be implemented by teachers 
as they were (e.g. Lesson plan 17). However, in most cases, the lesson plans offered more general curriculum material. The latter types of lesson plans included some combination of historical and chemical background information, together with general structure of the intended lesson. For example, Lesson plan 15 describes the structure of several lessons and offers descriptions of activities that can be used to meet the learning objectives. Teacher is also suggested several sources of further reading to understand the historical context of the lesson and the NOS topics to be discussed.

\subsection{Lesson Plans}

Three online collections were used as sources of lesson plans: The Minnesota Case Study Collection (MCSC) ${ }^{3}$, History and Philosophy in Science Teaching (HIPST) project website ${ }^{4}$ and The Story Behind the Science (SBS) website ${ }^{5}$. In addition, eight lesson plans created during a Finnish future teacher course (FTC) in chemistry education ${ }^{6}$ were also chosen for this study. From these sources, only the lesson plans labeled as chemistry-related were chosen. The decision to research only chemistry lesson plans was based on authors' background in chemistry education and the requirements of Finnish school system. ${ }^{7}$

The choice of the four collections of lesson plans to be analyzed was based on their utility for chemistry teachers. The MCSC, HIPST, and SBS websites were the only online sources found that offer freely available curriculum material for historical approach in chemistry education. They were also seen suitable for wide implementation as all three sources are informed by research on using historical approach to teach science and NOS (see Allchin 2011b; Clough 2009; Höttecke \& Riess 2009). The fourth source of lesson plans was chosen because it includes suitable material written in Finnish, which makes in important for Finnish chemistry education. The 25 chemistry-related lesson plans taken from these four sources and are listed in Table 1.

Table 1 Lesson plans chosen for further analysis.

\begin{tabular}{|c|c|c|}
\hline $\begin{array}{l}\text { Lesson } \\
\text { plan }\end{array}$ & Lesson plan name & Source \\
\hline 1 & Chemical and Human Resources, Parts $1 \& 2$ & MCSC \\
\hline 2 & Sucking Students Into an Understanding of Air Pressure and Vacuums & MCSC \\
\hline 3 & The Origins of Acids and Alkalis & MCSC \\
\hline 4 & The Chemistry of Fabric Dyes Chemical Reactions of the King of Colors: Indigo & $\mathrm{MCSC}$ \\
\hline 5 & Perfumes: Chemistry in 17th-Century French Courts & MCSC \\
\hline 6 & Cosmetics in Ancient Egypt & MCSC \\
\hline 7 & Rekindling Phlogiston & MCSC \\
\hline 8 & From Lavoisier to Dalton: Debating the Law of Definite Proportions & MCSC \\
\hline \multicolumn{3}{|c|}{ 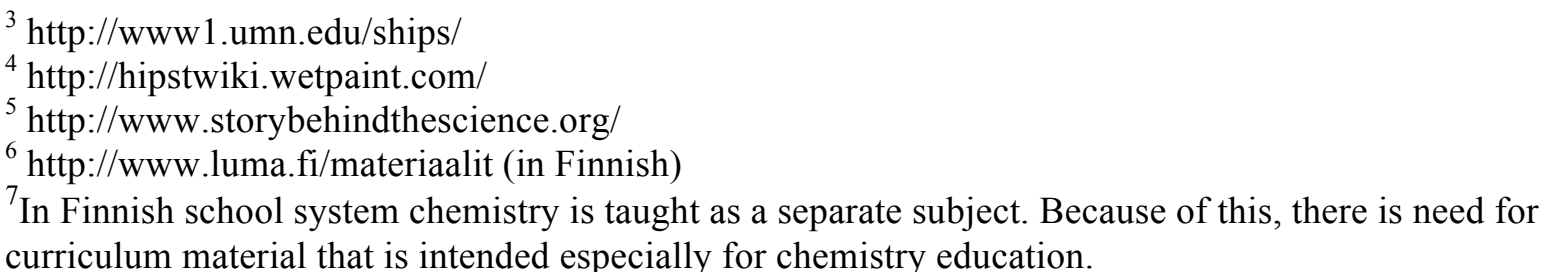 } \\
\hline
\end{tabular}




\begin{tabular}{lll}
9 & Determining Atomic Weights: The Role of Avogadro's Hypothesis & MCSC \\
10 & Splendor of the Spectrum: Bunsen, Kirchoff and the Origin of Spectroscopy & MCSC \\
11 & Faraday's Candle Observations & MCSC \\
12 & The Mendeleev Puzzle & MCSC \\
13 & Polymers and Serendipity Case Studies & MCSC \\
14 & Introduction of Topics of History of Energy in the Teaching of Physics and Chemistry & HIPST \\
15 & Is acidity perfect or real? & HIPST \\
16 & Chemical formulae and equations: more than just calculations? & HIPST \\
17 & A Puzzle with Many Pieces & SBS \\
18 & Fischer-Speier Esterification reaction & FTC \\
19 & Development of gas laws & FTC \\
20 & Amount of substance and concept of mole & FTC \\
21 & Periodic table & FTC \\
22 & Atomic models & FTC \\
23 & Acid and basic metal oxides & FTC \\
24 & Voltaic pile & FTC \\
25 & Le Chatelier's principle & FTC \\
\hline
\end{tabular}

MCSC = Minnesota Case Study Collection, HIPST $=$ History and Philosophy in Science Teaching wiki, SBS = The Story Behind the Science, FTC = Future Teacher Course.

All four sources of lesson plans described below aimed at explicit and reflective discussion of NOS. Both the stories in SBS and the case studies of MCSC are structured to include questions for students to discuss and reflect (see Allchin 2011b; Clough 2011). MCSC and HIPST case studies also emphasize the use student-centered teaching models (see Allchin 2011b; Höttecke \& Riess 2009).

\subsubsection{Minnesota Case Study Collection}

MCSC is a collection of historical case studies designed for engaging students into active and problem-based NOS and science learning (see Allchin 2011b). MCSC includes lesson plans for biology, chemistry, physics, earth sciences, and general science education. Of these, 13 chemistry-related were chosen for this study and are listed in Table 1.The narratives in the MCSC lesson plans are case studies interrupted with problems of scientific and metascientific nature. This structure and open-ended problems is seen to result in better learning. MCSC also emphasizes using authentic settings for the stories.

The MCSC lesson plans are designed with the focus on NOS content. Each lesson plan discusses some NOS “dimensions" (Allchin 2011b, p. 1264). These dimensions are based on the nature of whole science approach. This approach includes 10 NOS dimensions: observations and reasoning; methods of investigation; history and creativity; the human context; culture; social interactions among scientists; cognitive processes; economics/funding; instrumentation and experimental practices; and communication and transmission of knowledge (Allchin 2011 a, p. 525). In MCSC case studies, the NOS content is transformed from NOS statements to open problems for students to solve.

\subsubsection{History and Philosophy in Science Teaching Wiki}


The goal of the HIPST project was to "develop and disseminate well-approved materials for teaching and learning science with [history and philosophy of science]" (Höttecke \& Riess 2009 , p. 4). Most of the case studies created are related to physics, but there are also lesson plans for chemistry and biology and general science. The three lesson plans related to chemistry were chosen for analysis (see Table 1).

The HIPST working group sees the role of the narrative as central in a case study (see Henke et al. 2009, Höttecke et al. 2012). They have put great emphasis on making certain that the picture of the NOS given in a narrative is accurate. This requires quite broad stories which incorporate description of the societal setting and several other features. They describe the narrative as a story line, which focuses on one central idea. Narratives are utilized in HIPST case studies in various ways, for example as starting points or inspirations for lab work, or as source material for school theater productions.

The HIPST project does not subscribe any named NOS view. However, several suggestions for suitable NOS issues were given:

General characteristics of science are highlighted, for example the empirical and inferential NoS, the role of instruments, experiments, theories, models or specific skills of scientist and their helpers. Furthermore, showing the interrelation of society, culture and science is central. Science should be portrayed as a human and social endeavor; the portrayal must include perspectives on motivations of scientists, on conflicts, controversies and blind alleys. The role of trustworthiness, credibility and expertise, creativity and communication in establishing new knowledge, methods, instruments or material procedures are other important issues... (Höttecke et al. 2012, p. 1235)

HIPST uses guided-inquiry, replication of historical experiments and role-playing in its case studies. The narrative of case study is also central for NOS discussion (see Höttecke \& Riess 2009).

\subsubsection{Story Behind the Science}

The Story Behind the Science (SBS) project (see Clough 2011) has created stories 4-7 pages long to teach both NOS and science and to increase students' interest in science careers. Altogether 30 stories are under work for astronomy, biology, chemistry, geology and physics. Only one of the chemistry lesson plans was available at SBS website during this study (see Table 1).

The SBS stories use narratives to make discussion of NOS issues accessible for students. Narrative elements that could distort the NOS content are avoided. Distortion of NOS content means here creating science myths instead of portraying actual scientific work. The avoidable narrative elements are for example monumentality, idealization and affective drama. These could be used to make the narrative more interesting, but this would at the same time create falsified ideas about the history of science and NOS. SBS aims at describing science as human and creative action. Giving historically accurate picture of science informs students that scientific research is collaborative work and that it involves difficulties and 
human emotions. Learning about ontological and epistemological aspects of NOS is also mentioned, but the humane and creative aspects are given weight (Clough 2011, p. 703).

\subsubsection{Future Teacher Course}

The eight FTC lesson plans analyzed in this study were created by future chemistry teachers during a chemistry education course, held by authors. This course is part of the compulsory master's degree studies for chemistry education majors. FTC lesson plans were created by 16 future chemistry teachers during spring 2012.

All participating future teachers had completed at least one of the three practical teaching periods included in the pedagogical studies for teachers in Finland before taking the course. They also had taken majority of the chemistry courses required for their degree. The group was heterogeneous regarding their overall teaching experience and the stage of their studies. Some of the participants were finishing their master's degree while others were still without their bachelor's degree. Some of the participants in the former group were already working as chemistry teachers at schools.

Participating future chemistry teachers were instructed to design lessons for teaching both chemistry and NOS, and to use history as a context for the lesson. All groups were encouraged to include explicit discussion of NOS content in their lesson plans. They were introduced to different models for using history (e.g. drama, vignettes and historical experiments) during lessons. They were allowed to choose teaching models to be used freely. Models used were stories given for students to read (Lesson plan 19), dramatized dialogue or acting (Lesson plans 22 and 23), historical experiments (Lesson plan 24), learning games (Lesson plan 21) and oral representation of history (Lesson plans 18, 20, 21 and 25).

The lesson plans were designed to be used at comprehensive or upper secondary school level. The topics participants chose for the eight lessons plans are presented in Table 1. Each lesson plan was first tested at schools and then refined based on the experience. The final products were published in the Internet to support Finnish chemistry teachers in the use of historical approach.

\subsection{Method of Analysis}

The analysis of 25 lesson plans is described below. The analysis of NOS content and the use of historical experiments to teach this content is described in subsections 3.2.1 and 3.2.2, respectively. The analysis of the historical narratives is described in Subsection 3.2.3. The reliability and validity of analysis is discussed in Subsection 3.2.4.

\subsubsection{Analysis of Nature of Science Content}

To define whether NOS content is taught together with science, the 25 chemistry lesson plans were first analyzed to define learning objectives related to the learning science, history, 
inquiry skills or $\operatorname{NOS}^{8}$. Some lesson plans were ambiguous about the intended learning objectives. In these cases, the lesson plans were read through to define if NOS topics were discussed in them. Other categories of learning objectives were not pursued in this manner, as the focus of this study is on teaching NOS. The connection between NOS learning objectives and historical material in the lesson plans was also examined. If no connection between NOS learning objective and historical approach was found, the learning objective was not included in the analysis.

The preliminary categorization of the NOS learning objectives was grounded on the definitions of objectives given in the lesson plans. For example, explicitly stated objective "to show how science is cumulative group endeavor" (Lesson plan18) was labeled in the preliminary phase to be discussing communal aspect of science. If clearly articulated NOS learning objectives were not found, the discussion of NOS content in the lesson plan was analyzed to define probable learning objectives. For example, Lesson plan 3 did not clearly state NOS learning objectives. However, the lesson included following exercise: "Why is it important that Boyle was a member of the Royal Society? How does this strengthen his work as a scientist?" This exercise was interpreted as a NOS learning objective, categorized to "collaboration of scientists".

The discussion of NOS learning objectives in the lesson plan was labeled either implicit or explicit. Discussion was labeled as explicit when lesson plan included either instructions to discuss topic or exercises related to the NOS topic. An exercise described above is an example of latter. An example of explicit instruction can be found in Lesson plan 7:

Science as a process to explain and understand things based on observation and evidence has been the standard definition in my science class. I inform students of my belief that when students are asked to learn science concepts in class they are retracing similar steps that great science minds have taken to understand phenomenon (Lesson plan 7).

Discussion was implicit if the lesson plan merely mentioned the issue, but did not give any description of how to discuss it. For example, statement "students will be given the opportunity to think in a historical context, and they will be able to perform experiments to help gain an understanding of the development of acid-base theory" (Lesson plan 3) was seen as an implicit objective, because the lesson plan did not otherwise include any content that supports discussing this NOS aspect. Another example of implicit NOS learning objective was "science and the arts" in Lesson plan 5, as this topic was not discussed in the lesson plan after stating it in the introduction.

After the preliminary coding, the categories created were compared with the descriptions of domain general aspects of NOS (e.g. Lederman et al. 2002) as well as with the domain specific aspects of NOS in chemistry education (Vesterinen et al. 2013). In this study, these descriptions of central aspect of NOS were regarded more as general themes of discussion rather than specific truths to be memorized (see Clough 2007; Matthews 2012,

\footnotetext{
${ }^{8}$ Affective learning objectives (e.g. increasing students' interest in science) were outside of the scope of this study and were not analyzed.
} 
Vesterinen \& Aksela 2012). Each of the 18 identified NOS issue could be seen as a context specific example of nine more general NOS aspects described below:

- Tentative nature of chemistry. Scientific knowledge is durable but uncertain. This can be seen in historical changes of scientific knowledge. Tentativeness of chemistry includes also change in chemical instruments and creation of new substances. (see Lederman et al. 2002, Vesterinen et al 2013, p. 1844)

- Difference between laws and theories. Scientific laws are descriptive as theories are explanatory. Laws do not evolve to theories, or vice versa (see Lederman et al. 2002).

- Empirical nature of chemistry "contains discussion about the process of scientific inquiry as well as descriptions of scientific experiments and verification of scientific models through observations" (Vesterinen et al. 2013, p. 1845, see also Lederman et al. 2002).

- Chemistry is model-based. "Discussion on the role of models and modelling in chemistry and on the limitations of models are examples of this aspect" (Vesterinen et al. $2013 \mathrm{p}$. 1845).

- Inferential nature of chemistry. This aspect is related to the models as they are needed to infer submicroscopic phenomena in chemistry. Creativity is needed when these models are applied. (Vesterinen et al. 2013, see also Lederman et. al 2002)

- The role of creativity. Creating scientific knowledge and explanations is not based only on observations, but imagination and creativity are needed (Lederman et al. 2002).

- Instrumentation describes the "development of new instruments and how these instruments have affected research" (Vesterinen et al. 2013, p. 1846)

- Social dimensions of chemistry. There are various forms of social interactions inside and between research communities. Social aspects affect also publication of results and division of chemistry into sub disciplines. (see Lederman et al. 2002, Vesterinen et al. 2013)

- Societal dimensions of chemistry. Chemistry interacts with society and chemical industry affects chemistry as disciple (see Lederman et al. 2002, Vesterinen et al. 2013).

Even if usually combined as a single aspect, Social and societal dimensions were divided into two separate categories in this study. The learning objectives mentioning interactions inside science and between science and society were usually clearly distinguished in the lesson plans. Separating them in the analysis clarified the discussion of using historical approach to teach these aspects of NOS.

General characteristics of NOS issues discussed in the lesson plans are described in Subsection 4.1.

\subsubsection{Analysis of Historical Experiments}

The historical experiments presented in the lesson plans were analyzed to define how they were used to teach NOS. Based on suggestions how to use historical experiments described in Section 2.2, historical replications, physical replications and complementary experimentation were searched. If historical experimental setting was described and replicated, the experiment was categorized as replication. If the historical experiment was used as a starting point for 
students own experimentation, the experiment was categorized as complementary experiment. Category of history-inspired experiments was created after analyzing the lesson plans. This category includes experiments that are connected to the historical theme of the lesson, but do not use any experimental procedure rising from history. Experiments presented with no connection to historical approach in the lesson plan were not included in this analysis. Connections between historical experiments and NOS content were also analyzed to define which NOS issues historical experiments were used to discuss.

\subsubsection{Analysis of Historical Narratives}

The existing literature offers some tools to qualitatively assess narratives (e.g. Norris et al. 2005). To gain new understanding of the content and more specifically of the use of narratives, the categorization of narratives was created based on grounded theory content analysis. It is based on the chemistry lesson plans available from HIPST, MCSC and SBS. The categorization created was then used to categorize the narratives in the FCT lesson plans. The categories created are described in Subsection 4.3.

First step of analysis was writing short descriptions of the lesson plans and the narratives included in them. From these descriptions, common features of narratives were identified. The features of the narratives chosen for closer analysis are described below. If lesson plan included more than one narrative, each narrative was analyzed separately.

From the short descriptions written, the focus of each narrative was analyzed. Three broad categories were created based on analysis of foci.

The placement of narratives and their use together with exercises varied between narratives. Several categories were created for the placement and use of the narratives in the lesson plans.

The characters in the narratives were sometimes active in making science and sometimes non-scientific. It was also noted that the degree of detail, in which characters' actions were described, varied greatly.

Different types of characters in the narratives were analyzed. Drawing the line between minor and major role of characters' in the description of scientific progress in lesson plans and between detailed and superficial description of their work, turned out to be difficult. Thus, it was decided to only analyze the amount of people who were mentioned to contribute into the scientific work.

One more class of characters rose from the narratives. It seemed that some narratives included characters who were described in a way that could be described as a view point character. These were characters whose motives and feelings were described in such detail that reader is able to have emotional contact surface with the character and the reader is lead to understand the motives of the character.

Finally conflicts in the narratives were also analyzed. From the short descriptions it was evident that many stories included conflicts as central parts of the narrative and many mentioned some as well. Conflicts were broadly defined as any situation with opposing interests or similar controversy between characters or ideas in the narrative and categories for central and non-central conflicts were created. 


\subsubsection{Reliability and Validity}

Some of the lesson NOS content in the lesson plans does not show in this analysis. If lesson plans state NOS learning objectives, the rest of the lesson plan was analyzed only to define the explicitness of the discussion. Therefore the lesson plans most likely include discussion of NOS issues unrelated to the stated learning objectives of the lesson plan. Also, the historical background in the lesson plan may be suitable for teaching NOS content not mentioned in the lesson plans.

Results of this study do not represent the MCSC, HIPST and SBS projects. The chemistry lesson plans in each of these projects is only a fraction of the total lesson plans and the lesson plans alone are not enough to review how they are used in classroom, as the projects offer additional information for teachers on how to use the material created. ${ }^{9}$ Therefore, this study does not pay attention on whether the stated objectives of the four projects were met in the lesson plans analyzed.

Nonetheless, the analysis described in this section allows giving a valid and reliable description of the possibilities for the use of the material created by teachers and educators outside the four projects where lesson plans were created. It is impossible to know how teachers implement the lesson plans. However, it seems reasonable to argue that the stated NOS topics and exercises, together with historical narratives, will guide these decisions.

\section{Results}

Lesson plans meet the requirement of integrating NOS teaching with traditional science teaching (Höttecke \& Silva 2011). 20 lesson plans (80\% of total) include science content knowledge learning objectives, 11 (44\%) include history content knowledge learning objectives and 11 (44\%) include inquiry skills learning objectives. Inclusion of earning objectives related to science, history, NOS or inquiry is presented in Table 2.

The structure of historical approach in lesson plans analyzed is usually similar to a case study and historical vignettes are not used. This is understandable when use of case studies was suggested in the objectives of both MCSC and HIPST (Allchin 2011b, Höttecke \& Riess 2009). Some lesson plans (e.g. lesson plans 15 and 16) cover more than one lesson and use historical approach similar to the thematic narrative (Stinner et al. 2003).

Lesson plans 1 and 11 do not include any specific NOS-related learning objectives. Lesson plan 1 focuses on learning historical biographies and science, and in lesson plan 11 the focus is on using historical experiments to support students' inquiry skills. They both may be suitable for teaching NOS, but the specific learning objectives are left for teacher to choose and design.

Table 2 Inclusion of science, history, inquiry and NOS learning objectives in the lesson plans $(\mathrm{N}=25)$.

\footnotetext{
${ }^{9}$ See http://www1.umn.edu/ships/initiate.htm for MCSC and http://www.storybehindthescience.org/support.html for SBS. HIPST offered a link to MCSC guidelines. Review of FTC project is outside the scope of this study.
} 


\begin{tabular}{|c|c|c|c|c|}
\hline No. of lesson plan & $\begin{array}{l}\text { Knowledge of } \\
\text { science }\end{array}$ & $\begin{array}{l}\text { Knowledge of } \\
\text { history }\end{array}$ & Inquiry skills & Knowledge of NOS \\
\hline \multicolumn{5}{|l|}{$\mathrm{MCSC}$} \\
\hline 1 & $\mathrm{X}$ & $\mathrm{X}$ & & \\
\hline 2 & $\mathrm{X}$ & & $\mathrm{X}$ & $\mathrm{X}$ \\
\hline 3 & $\mathrm{X}$ & $\mathrm{X}$ & & $\mathrm{X}$ \\
\hline 4 & $\mathrm{X}$ & $\mathrm{X}$ & $\mathrm{X}$ & $\mathrm{X}$ \\
\hline 5 & $\mathrm{X}$ & $\mathrm{X}$ & $\mathrm{X}$ & $\mathrm{X}$ \\
\hline 6 & & $\mathrm{X}$ & $\mathrm{X}$ & $\mathrm{X}$ \\
\hline 7 & $X$ & & & $X$ \\
\hline 8 & $\mathrm{X}$ & & $\mathrm{X}$ & $\mathrm{X}$ \\
\hline 9 & $\mathrm{X}$ & & & $\mathrm{X}$ \\
\hline 10 & & & & $\mathrm{X}$ \\
\hline 11 & & & $\mathrm{X}$ & \\
\hline 12 & & & $\mathrm{X}$ & $\mathrm{X}$ \\
\hline 13 & $\mathrm{X}$ & & & $\mathrm{X}$ \\
\hline \multicolumn{5}{|l|}{ HIPST } \\
\hline 14 & $\mathrm{X}$ & & & $\mathrm{X}$ \\
\hline 15 & $\mathrm{X}$ & $\mathrm{X}$ & $\mathrm{X}$ & $\mathrm{X}$ \\
\hline 16 & $\mathrm{X}$ & $\mathrm{X}$ & $\mathrm{X}$ & $\mathrm{X}$ \\
\hline \multicolumn{5}{|l|}{ SBS } \\
\hline 17 & & & & $\mathrm{X}$ \\
\hline \multicolumn{5}{|l|}{ FTC } \\
\hline 18 & $\mathrm{X}$ & $\mathrm{X}$ & $\mathrm{X}$ & $\mathrm{X}$ \\
\hline 19 & $\mathrm{X}$ & $\mathrm{X}$ & & $\mathrm{X}$ \\
\hline 20 & $\mathrm{X}$ & & & $\mathrm{X}$ \\
\hline 21 & $\mathrm{X}$ & $X$ & & $\mathrm{X}$ \\
\hline 22 & $\mathrm{X}$ & & & $\mathrm{X}$ \\
\hline 23 & $\mathrm{X}$ & $\mathrm{X}$ & & $\mathrm{X}$ \\
\hline 24 & $X$ & & & $\mathrm{X}$ \\
\hline 25 & $\mathrm{X}$ & & $\mathrm{X}$ & $\mathrm{X}$ \\
\hline
\end{tabular}

MCSC $=$ Minnesota Case Study Collection, HIPST $=$ History and Philosophy in Science Teaching wiki, SBS = The Story Behind the Science, FTC = Future Teacher Course.

\subsection{History-Related Nature of Science Content in the Lesson Plans}

Lesson plans used the historical approach mostly to discuss the tentative nature of science ( $48 \%$ of the lesson plans), the empirical nature of science (52\%), the social dimensions of science (32\%), the societal dimensions of science $(20 \%)$ and the role of models in science (24\%). Inferential nature of science, role of creativity, the difference between laws and theories, and instrumentation were aspects discussed by single lesson plan each.

Other NOS aspects include discussion of several different NOS issues. Different issues found from the lesson plans and the number of lesson plans discussing them is presented in Table 3.

Table 3 NOS categories and the number of lesson plans including history-related learning objectives from each category. The percentage of total amount of 25 lesson plans discussing each topic is given in parenthesis. 
Tentative

Change of scientific knowledge

$10(40 \%)$

Conceptual change

$4(16 \%)$

Differences between laws and theories

Definitions of law and theory, differences between the two.

$1(4 \%)$

Empirical

Scientific discovery process

$9(36 \%)$

Relationship between theoretical and empirical aspects of science

$6(24 \%)$

Relationship between empirical evidence and models

$1(4 \%)$

Model-based

Realism of models

$3(12 \%)$

Limitations and context-relatedness of models

$5(20 \%)$

Development of models

$1(4 \%)$

Semiotics of models

$1(4 \%)$

Inferential

Theories as tools to interpret phenomena

Creativity

Role of creativity and imagination in doing science and solving scientific puzzles

Social dimensions

Collaboration of scientists

Power and politics within scientific community

Societal dimensions

Influence of larger cultural milieu to scientific practice and knowledge

Relationship between science and industry

Relationship between chemistry and commerce

Instrumentation

Role of scientific instruments

$1(4 \%)$

Of the 23 lesson plans where NOS was discussed in historical context, only two lesson plans (12 and 24) do not include explicit discussion. In Lesson plan 24, it is assumed that description of the experimental work of Volta and Galvani would teach students about the empirical nature of chemistry. In Lesson plan 12 NOS is discussed explicitly, but not in a historical context. It uses historical approach to discuss only implicit NOS learning objectives. In five lesson plans, some NOS aspect are discussed implicitly and others explicitly. Inclusion of explicit and implicit discussion of the nine NOS aspect is presented in Table 4. If both explicit and implicit learning objectives from the same category were presented in a lesson plan, the mention was marked as explicit.

Table 4 Inclusion of history-related NOS learning objectives categorized by different NOS aspects.

\begin{tabular}{|c|c|c|c|c|c|c|c|c|c|}
\hline $\begin{array}{l}\text { No. of } \\
\text { Lesson } \\
\text { plan }\end{array}$ & $\begin{array}{l}\text { Tentat } \\
\text { ive }\end{array}$ & $\begin{array}{c}\text { Difference } \\
\text { between } \\
\text { laws and } \\
\text { theories }\end{array}$ & $\begin{array}{l}\text { Empir } \\
\text { ical }\end{array}$ & $\begin{array}{l}\text { Mode- } \\
\text { based }\end{array}$ & $\begin{array}{l}\text { Inferen } \\
\text { tial }\end{array}$ & $\begin{array}{l}\text { Creativi } \\
\text { ty }\end{array}$ & $\begin{array}{c}\text { Social } \\
\text { dimension } \\
\mathrm{s}\end{array}$ & $\begin{array}{c}\text { Societal } \\
\text { dimensio } \\
\text { ns }\end{array}$ & $\begin{array}{l}\text { Instrumenta } \\
\text { tion }\end{array}$ \\
\hline
\end{tabular}




\begin{tabular}{|c|c|c|c|c|c|c|c|c|c|}
\hline \multirow{2}{*}{\multicolumn{10}{|c|}{2}} \\
\hline & & & & & & & & & \\
\hline 3 & I & & & & & & E & & \\
\hline 4 & & & E & & & & & E & \\
\hline 5 & & & I & & & & & E & \\
\hline 6 & & & E & & & & E & E & \\
\hline 7 & E & & I & E & & & & & \\
\hline 8 & E & & E & E & & & & E & \\
\hline 9 & E & & & & & & E & & \\
\hline 10 & I & & & & & & E & & E \\
\hline 11 & & & & & & & & & \\
\hline 12 & & & I & I & & & & & \\
\hline 13 & & & E & & & & & & \\
\hline \multicolumn{10}{|c|}{ HIPST } \\
\hline 14 & & & E & & E & & E & & \\
\hline 15 & I & & E & & & & & & \\
\hline 16 & & & & E & & & & & \\
\hline \multicolumn{10}{|l|}{ SBS } \\
\hline 17 & E & E & E & & & E & E & & \\
\hline \multicolumn{10}{|l|}{ FTC } \\
\hline 18 & E & & E & & & & E & & \\
\hline 19 & E & & & E & & & & & \\
\hline 20 & E & & & & & & & & \\
\hline 21 & E & & & & & & E & & \\
\hline 22 & & & & E & & & & & \\
\hline 23 & E & & & & & & & & \\
\hline 24 & & & I & & & & & & \\
\hline 25 & & & & & & & & E & 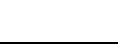 \\
\hline
\end{tabular}

Several NOS issues are discussed in the lesson plans. The issues are described below, using the nine NOS aspects for structuring the conversation. A number of the recognized NOS issues are can be seen related to more than one general NOS aspect. However, for the sake of clarity, in Table 3 each identified NOS issue is connected with only one general NOS aspect.

\subsubsection{Tentative}

12 lesson plans discuss tentativeness of scientific knowledge. Historical narratives are used to show how knowledge changes gradually during long periods of time. Chemical concepts from different periods of history are described and compared, as are solutions of historical problems. Chronological descriptions of a single chemist's work are also given to illustrate the development of knowledge and ideas.

Ten lesson plans $(3,7,8,10,17,18,19,21,23$ and 24) used historical approach to discuss the general (1) change of scientific knowledge. Here the emphasis is on showing that change exists and describing the general mechanisms of this change. For example, Lesson plan 23 aims at teaching that "scientific knowledge is durable but uncertain". This is done by discussing work of Lavoisier and asking students to consider why some of the Lavoisier's ideas were correct and some were later proven wrong. 
Four lesson plans (3, 7, 9 and 20) use historical approach to discuss (2) conceptual change. Scientific concepts from different historical periods are presented and their change explained. For example, in Lesson plan 3 students are introduced to several definitions of acidity from ancient Greek to the 17th century Europe. This approach aims at helping students to "gain an understanding of the development of acid-base theory". Rivalry between different concepts is also used to discuss the tentativeness of science. In Lesson plan 9, the difficulties related to accepting the idea of diatomic gases of single element are used to discuss the conceptual change.

\subsubsection{Difference between Laws and Theories}

The difference between laws and theories is discussed explicitly only in Lesson plan 17. Students are instructed to read a story about the development of periodic table and to pay attention to the idea that "scientific laws and theories are different forms of knowledge". This idea is then explained using "Mendeleev's Periodic Law" as an example. The story continues with description of Mendeleev's reaction to the discovery of noble gases and radioactivity, both of which went against Mendeleev's theories related to the periodicality and the nature of matter. Later on in the lesson plan, students' attention is again directed to the definition of laws and theories.

\subsubsection{Empirical}

Issues related to empirical nature of scientific knowledge are discussed in 13 lesson plans. Several lesson plans focus on describing the difference between scientific experimentation and similar nonscientific work. Eight of the 13 lesson plans use historical experiments to support discussing empirical nature of science (see also Subsection 4.2).

(1) Scientific discovery process is discussed in nine lesson plans (2, 4, 5, 6, 8, 13, 14, 17 and 24). Often the aim is to inform students of the role of empirical practices in science and Lesson plans 4, 5 and 8 explicitly name nature of scientific discovery as one of their NOS learning objectives and describe historical discovery processes. Lesson plans 4, 5 and 6 discuss how past cultures had learned to manufacture dyes, perfumes and cosmetics, respectively. In Lesson plan 2 the history-inspired experiments are used to show "Science as a process to explain and understand things based on observation and evidence" and Lesson plan 17 discusses the alternatives to scientific method in knowledge production. Role of chance in scientific discovery is discussed in Lesson plan 13.

In six lesson plans $(6,7,8,12,13$ and 18) the (2) relationship between empirical and theoretical aspects of science is discussed. Historical narratives are used to provide examples of how scientists use experimental work, theoretical framework, and hypotheses to create new knowledge. Lesson plan 8 aims to "explain the process and nature of scientific discovery, as exemplified in the case of the development and acceptance of Dalton's atomic theory". This is done by describing experimental work of Proust and Berthollet, and the disagreement between these two scientists on the proportion of atoms in compounds.

In Lesson plan 7, students own experimentation is used to show them "how real research in science proceeds: as a balance between blind groping, reasoned guesses about 
where to go next, and empirical confirmations" In Lesson plan 6, students are first introduced to how cosmetics were manufactured in ancient Egypt, after which they are asked to discuss the difference between chemists experimental work and practical work done by cosmetics manufacturers in ancient Egypt.

Lesson plan 15 uses historical approach to discuss the (3) relationship between empirical evidence and models. Different historical definitions and models for acids are described, together with experimental identification methods. The objective of the lesson is to teach both the role of empirical evidence in creating models, and the role of models in experimentation.

\subsubsection{Model-Based}

Model-based view on science is presented in six lesson plans. Simplified historical models are presented for students. This allows students to discuss and evaluate the (1) realism of models which is discussed in three lesson plans (7, 16 and 22). In Lesson plan 7, historical model of phlogiston and the related theories are presented for students and they are instructed to explain oxidation and reduction using phlogiston theory. Later in the lesson plan electrons are introduced and used for same purpose, after which students are expected to discuss "models and realism in science, the possible tension between simple and complex models or theories, and conceptual change". In Lesson plan 22 students are asked to evaluate "pros and cons" of Bohr and Lewis atomic models and they are told that "there is no one right way to present models".

Five lesson plans $(7,8,12,16$, and 22) discuss the (2) limitations and contextrelatedness of models. Again, simplified versions of historical models are presented for students to discuss. Historical approach is used to give enough perspective for enabling students to understand the historical context where the models were created and how they were later found limited in other context. In Lesson plan 12 students' are asked to create their own periodic tables based on the properties of elements. In this lesson plan, Mendeleev's table, its creation and use, are also used as an example to "show how our theories or representation reflect specific purposes".

Lesson plan 19 includes a learning objective related to the (3) development of models: "development of chemical models through time as a collaborative work of several researchers". This discussion is connected with teaching about the tentativeness of scientific knowledge.

Lesson plan 16 includes learning objectives related to the (4) semiotics of models. The lesson plan discusses the development of chemical symbolism and equations. The historical context for this discussion is the development of models and theories of chemical compounds and chemical change. As the discussion touches both the development of the models and theories as well as the influence of larger cultural milieu, discussion of the semiotics of models in Lesson plan 16 is connected with both the tentativeness of scientific knowledge and with the societal dimensions of science.

\subsubsection{Inferential}


In Lesson plan 14, history is used to discuss theories as tools to interpret phenomena, which is an aspect of the inferential nature of science. Development of theories related to energy is described, together with problems arising from the use of related concepts in different situations:

The variety of theses concerning the nature of heat, falling of bodies, energy and the fact that these theses were used to explain phenomena highlight an important characteristic of science: scientific theories include an interpretation of phenomena. (Lesson plan 14)

\subsubsection{Creativity}

The role of creativity and imagination in creating explanations and solving scientific puzzles is discussed in Lesson plan 17. Other lesson plans also refer to the role of creativity in science, but only in Lesson plan 17 it is discussed as an independent NOS topic. The long time between Avogadro's proposal of his theories and the acceptance of those ideas by scientific community is presented and students are asked to explain how it demonstrates "that creative insight is crucial in science". In the same lesson plan, students are asked "how does [Mendeleev's] work illustrate that doing science requires creativity and imagination"

\subsubsection{Social Dimensions}

Eight lesson plans treat the social dimensions of science. Seven lesson plans (3, 6, 10, 14, 17, 18 and 21) discuss the importance of (1) collaboration of scientists. Importance of scientific organizations and events are discussed in lesson plans 3 and 17. Former discussed the role of the Royal Society in Boyle's work. In Lesson plan 17 the importance of Karlsruhe conference is used as an example to show that: "doing science well requires significant collaboration with others... Science is not the solitary undertaking that many people think". Other lesson plans discuss the role of collaboration by describing how several scientists have worked together to solve problems. In Lesson plan 10 the collaboration and friendship between Bunsen and Kirchoff is the central theme of the narrative.

Lesson plan 9 discusses the role of (2) power and politics within scientific community. It introduces students to the "role of persuasion and politics in science" and explains the slow acceptance of Avogadro's results by scientific community by stating that: "as noted earlier, Avogadro is not a very reputable chemist". It also presents Berzelius as being "very wellrespected and considered the authority on this subject" which hindered the acceptance of Avogadro's rival theory.

\subsubsection{Societal Dimensions}

Societal dimensions of science are discussed extensively in five lesson plans. Historical examples are mostly used to show the (1) influence of larger cultural milieu to scientific practice and knowledge, which is discussed in four lesson plans (4, 5, 6 and 8). For example in the Lesson plan 4, the students are introduced to past methods of dye producing and asked to "explore chemical reactions from the perspective of people of the period being explored". 
Also Lesson plan 6 discusses several cultural and societal factors in the context of manufacturing cosmetics. It presents the practical methods of ancient Egypt for creating eye makeup. These methods were used as basis for discussing the different factors affecting the development of science in the past and nowadays. Technology is listed as one of these factors, but not discussed extensively.

Chemistry has been closely related with industry and much of the chemical research has been and still is use inspired. In Lesson plan 25, the (2) relationship between science and industry is discussed by describing how the requirements of agriculture and industry guided the Fritz Haber's research on ammonia synthesis.

The (3) relationship between chemistry and commerce is discussed in two lesson plans. Lesson plan 4 discusses the economic impacts of scientific discoveries as students are prompted to explore "the economic impact of indigo on dye-producing countries and the old and new worlds". Economic needs affect the practice of chemistry especially through funding. This is explicitly acknowledged in Lesson plan 6 by asking students to name factors "that go into the development of cosmetics by people in our country today".

\subsubsection{Instrumentation}

Role of scientific instruments in the empirical process and development of scientific practice and knowledge is discussed in lesson plan 10. Students are introduced to the work of three scientists who developed and refined Bunsen burner. The significance of this technological product for science is mentioned: "[Bunsen burner] would later play a central role in opening a major new field of chemical analysis: spectroscopy". This issue is closely related also to the empirical and tentative NOS aspects.

\subsection{Historical Experiments}

Historical experiments are connected to NOS content in 11 lesson plans (44\% of the total 25 lesson plans) and four lesson plans include historical experiments with no connection to NOS content. Of the 11 lesson plans, seven include (1) history-inspired experiments. For example, Lesson plan 3 has students to identify acids with carbonates and indicators, based on work done by Glauber and Boyle. Three of the 11 lesson plans include (2) physical replications of historical experiments (e.g. building Voltaic pile using modern equipment in Lesson plan 24). Historical replications are not used in any of the lesson plans.

In Lesson plan 7 experiments are conducted in a way that resembles (3) complementary experimentation. Students are introduced to phlogiston theory, which could be counted as part of the complementary science. They are instructed to perform experiments and explain the results obtained using the theoretical framework and model of phlogiston. The structure of experimentation is also similar to representation of historical experiment, where students are allowed to design their own experiments inspired by historical background (Metz \& Stinner 2006).

Historical experiments are mainly used to teach empirical or tentative nature of science. This agrees with suggestion of using historical experiments to teach about the processes of science (Allchin 2000). In two lesson plans (14 and 15) physical replications of historical 
experiments are used to teach about the role of experiments in the production of new knowledge, as suggested by Höttecke (2000).

The role of experimentation is often to illustrate the phenomena discussed and they are rarely instrumental part of teaching the NOS topic. For example, in Lesson plan 3 the experiments inspired by Glauber and Boyle are connected to the NOS aspect of the lesson (i.e. development of acid-base theory) but conducting the experiments do not seem to be integral for this learning objective to be met.

History-inspired experiments have central role in Lesson plan 18. Students are first told about the role of collaboration in the development of organic synthesis, after which they work as a team to hypothesize reaction mechanism in the esterification reactions. Table 5 shows the types of historical experiments used and their connections to NOS aspects.

Table 5 Types of historical experiments used to teach different NOS aspects.

\begin{tabular}{|c|c|c|c|c|c|c|c|c|c|}
\hline $\begin{array}{l}\text { No. of } \\
\text { Lesson } \\
\text { plan }\end{array}$ & Tentative & $\begin{array}{c}\text { Difference } \\
\text { between } \\
\text { laws and } \\
\text { theories }\end{array}$ & Empirical & $\begin{array}{l}\text { Model- } \\
\text { based }\end{array}$ & Inferential & $\begin{array}{l}\text { Creat- } \\
\text { ivity }\end{array}$ & $\begin{array}{c}\text { Social } \\
\text { dimen- } \\
\text { sions }\end{array}$ & $\begin{array}{c}\text { Societal } \\
\text { dimen- } \\
\text { sions }\end{array}$ & $\begin{array}{c}\text { Instru- } \\
\text { mentation }\end{array}$ \\
\hline \multicolumn{10}{|l|}{ MCSC } \\
\hline 2 & & & $\mathrm{H}$ & & & & & & \\
\hline 3 & $\mathrm{H}$ & & & & & & & & \\
\hline 4 & & & $\mathrm{H}$ & & & & & $\mathrm{H}$ & \\
\hline 5 & & & $\mathrm{H}$ & & & & & $\mathrm{H}$ & \\
\hline 6 & & & $\mathrm{H}$ & & & & & & \\
\hline 7 & $\mathrm{C}$ & & $\mathrm{C}$ & $\mathrm{C}$ & & & & & \\
\hline \multicolumn{10}{|l|}{ HIPST } \\
\hline 14 & & & $\mathrm{P}$ & & & & & & \\
\hline 15 & & & $\mathrm{P}$ & & & & & & \\
\hline 16 & & & & $\mathrm{P}$ & & & & & \\
\hline \multicolumn{10}{|l|}{ SBS } \\
\hline \multicolumn{10}{|l|}{ FTC } \\
\hline 18 & $\mathrm{H}$ & & $\mathrm{H}$ & & & & & & \\
\hline 23 & $\mathrm{H}$ & & & & & & & & \\
\hline
\end{tabular}

\subsection{Narratives in the Lesson Plans}

In the analyzed lesson plans the history of science is usually presented in a narrative form. For example, in the SBS lesson plan the narrative is a text to be read in the classroom either by the students or by the teacher. Most MCSC lesson plans feature the teacher as the storyteller and include one central story with connected exercises.

The 25 lesson plans analyzed include only three lesson plans (2, 7 and 12), which do not include a recognizable narrative as part of the classroom instruction. In these three lesson plans, the teacher is provided with information about the history in the form of a narrative. In 
lesson plan 7 it is clearly a pedagogical choice from the authors to exclude the actual narrative from the lesson plan. In others the intention might be to introduce students to the narrative at some point. However, the lesson plans do not directly instruct to do so. These three lesson plans could be described as efforts on creating historically informed learning environments. In all of them some historical information (Faraday's candle experiments, phlogiston theory or experiments on pressure) is used as inspiration to create a meaningful learning environment and to teach several contents. The students however would be only vaguely aware of their work's connection to history, and according to the presented lesson plans, might not learn anything about past scientists or their work. Instead their own work would mimic the scientific work of the past and it would be used to teach the students NOS, among other things.

Most lesson plans include only one narrative but some include several. Where multiple narratives are included, these narratives have very little to do with each other, except for the general topic. Lin and colleagues (2010) describe the use of four storylines that the students could follow simultaneously. This would help them to gain better understanding of the different aspects of the development of the same phenomenon. This approach is not used in any of the analyzed lesson plans with multiple narratives.

\subsubsection{Placement and Use of the Narratives}

The use of the narrative was also analyzed. Four categories were formed to describe how the narrative was included in the lesson plan. The number of narratives in each lesson plan and the use of each narrative is presented in Table 6.

Ten lesson plans use a narrative in a comprehensive way meaning that the lesson are built around one central narrative and that all the exercises are connected to the narrative. Connected exercises use information from the narrative or have some other direct contact with the narrative. For example, in lesson plan 5 the narrative ends with an assignment given by a character in the narrative. In lesson plan 19 the students read a narrative about the life of Charles, Gay-Lussac or Boyle and then act out a fictive interview of the scientist. In lesson plan 10 the storyline is interrupted with tasks like: "What may account for the appearance of dark lines in the place of bright sodium lines? How would you investigate your idea further?"

Two lesson plans use the narrative as a background, from which students moved to unrelated exercises, and then back to the narrative. Four lesson plans use narrative as an introduction to exercises or activities. These exercises are not directly connected to the narrative and the narrative is not returned to. This is the case in Lesson plan 24 where a lecture of the work of Volta and Galvani is first described, after which the lesson plan moves on to building a Volta's pile and making exercises about electricity and structure of matter, without using any information from the narrative.

Seven lesson plans use narrative as a deviation from the actual lesson. In some lesson plans these deviations are homework where the students were asked to find out more about a short narrative (e.g. lesson plans 1 and 11). In lesson plan 20 the lesson is built around chained narratives that however are not linked to each other except by the teacher's presentation of modern theory in between the historical deviations. 
The lesson plans 15 and 16 re so vague about how to use the narrative that categorizing them was not possible. In Table 6 the use of narrative is marked as unclear for these two narratives. 
Table 6 The number of narratives for each lesson plan and the results of the analysis on the use and foci of narratives, number of characters in narratives and whether or not the narratives include a conflict. For lesson plans with more than one narrative, each narrative is categorized separately.

\begin{tabular}{|c|c|c|c|c|c|c|c|}
\hline \multicolumn{2}{|c|}{$\begin{array}{l}\text { Lesson plan and } \\
\text { narratives }\end{array}$} & \multirow[t]{2}{*}{ Use of narrative } & \multicolumn{3}{|c|}{ Foci of the narrative } & \multirow[t]{2}{*}{$\begin{array}{l}\text { Multiple } \\
\text { characters }\end{array}$} & \multirow[t]{2}{*}{$\begin{array}{l}\text { Includes a } \\
\text { conflict }\end{array}$} \\
\hline & & & $\begin{array}{l}\text { Scientific } \\
\text { process }\end{array}$ & $\begin{array}{l}\text { Concepts or } \\
\text { models }\end{array}$ & $\begin{array}{l}\text { Personal } \\
\text { history }\end{array}$ & & \\
\hline \multicolumn{8}{|c|}{$\mathrm{MCSC}$} \\
\hline \multirow[t]{6}{*}{1} & $1 \mathrm{a}$ & deviation & & & & & \\
\hline & $1 b$ & deviation & & & & & \\
\hline & $1 \mathrm{c}$ & deviation & & & & & \\
\hline & $1 d$ & deviation & & & & & \\
\hline & $1 \mathrm{e}$ & deviation & & & & & \\
\hline & 1f & deviation & & & & & \\
\hline 2 & - & - & & & & & \\
\hline 3 & 3 & comprehensive & $\mathrm{X}$ & & & $\mathrm{X}$ & $\mathrm{X}$ \\
\hline \multirow[t]{2}{*}{4} & $4 a$ & background & & $\mathrm{X}$ & & & \\
\hline & $4 b$ & deviation & & & & & \\
\hline 5 & 5 & comprehensive & & $X$ & & & \\
\hline 6 & 6 & comprehensive & & & & & \\
\hline 7 & - & - & & & & & \\
\hline 8 & 8 & comprehensive & $\mathrm{X}$ & & & $X$ & $X$ \\
\hline 9 & 9 & comprehensive & $\mathrm{X}$ & & & $X$ & $\mathrm{X}$ \\
\hline 10 & 10 & comprehensive & $\mathrm{X}$ & $\mathrm{X}$ & $X$ & $\mathrm{X}$ & $\mathrm{X}$ \\
\hline 11 & 11 & deviation & & & & & \\
\hline 12 & - & - & & & & & \\
\hline \multirow[t]{5}{*}{13} & $13 \mathrm{a}$ & introduction & $\mathrm{X}$ & & & & \\
\hline & $13 b$ & introduction & $X$ & & & & \\
\hline & $13 c$ & introduction & $\mathrm{X}$ & & & & \\
\hline & $13 \mathrm{~d}$ & introduction & $\mathrm{X}$ & & & $X$ & \\
\hline & $13 \mathrm{e}$ & introduction & $X$ & & & & \\
\hline \multicolumn{8}{|c|}{ HIPST } \\
\hline 14 & 14 & deviation & & $\mathrm{X}$ & & $\mathrm{X}$ & $\mathrm{X}$ \\
\hline 15 & 15 & unclear & & & & $\mathrm{X}$ & $\mathrm{X}$ \\
\hline 16 & 16 & unclear & & $\mathrm{X}$ & & $\mathrm{X}$ & $X$ \\
\hline \multicolumn{8}{|l|}{ SBS } \\
\hline 17 & 17 & comprehensive & $X$ & & & $X$ & $X$ \\
\hline \multicolumn{8}{|l|}{ FTC } \\
\hline 18 & 18 & deviation & $\mathrm{X}$ & $\mathrm{X}$ & & $X$ & \\
\hline \multirow[t]{3}{*}{19} & $19 a$ & comprehensive & & $\mathrm{X}$ & $X$ & $X$ & $X$ \\
\hline & $19 b$ & comprehensive & & $\mathrm{X}$ & $\mathrm{X}$ & $X$ & \\
\hline & $19 \mathrm{c}$ & comprehensive & & $X$ & $\mathrm{X}$ & $X$ & \\
\hline \multirow[t]{3}{*}{20} & $20 \mathrm{a}$ & deviation & & $\mathrm{X}$ & & $\mathrm{X}$ & \\
\hline & $20 b$ & deviation & & $\mathrm{X}$ & & & \\
\hline & $20 c$ & deviation & & $\mathrm{X}$ & & & $\mathrm{X}$ \\
\hline 21 & 21 & comprehensive & $\mathrm{X}$ & & & $\mathrm{X}$ & $X$ \\
\hline 22 & 22 & introduction & & $\mathrm{X}$ & & $\mathrm{X}$ & $\mathrm{X}$ \\
\hline \multirow{2}{*}{23} & $23 a$ & comprehensive & & $\mathrm{X}$ & & & $\mathrm{X}$ \\
\hline & $23 b$ & deviation & & X & & $X$ & $X$ \\
\hline 24 & 24 & introduction & $X$ & $X$ & & $X$ & $\mathrm{X}$ \\
\hline \multirow[t]{3}{*}{25} & $25 \mathrm{a}$ & introduction & & & $\mathrm{X}$ & & \\
\hline & $25 b$ & background & $X$ & $X$ & & $X$ & \\
\hline & $25 c$ & introduction & $X$ & & & $X$ & \\
\hline
\end{tabular}

MCSC $=$ Minnesota Case Study Collection, HIPST $=$ History and Philosophy in Science Teaching wiki, SBS = The Story Behind the Science, FTC = Future Teacher Course.

\subsubsection{Foci of the Narratives}


The narratives were analyzed based on the foci of the narrative. Three categories were formed: (i) scientific process; (ii) concepts, content and models; and (iii) personal history. The focus or foci of each narrative is presented in Table 6 .

Here, scientific process means the act of practicing scientific research. For example, in lesson plan 3 the scientific process is tracked for several centuries starting from ancient Greece and ending with Glauber and Boyle. Much scientific work and several discoveries are described.

In ancient times, the Egyptians and Greeks defined certain substances based upon their taste. Both the Greeks and the Egyptians had discovered that one particular substance was very sour. This became to be known as vinegar, which was produced from the fermentation of fruits to produce wine. Therefore, a new categorization of substances was developed that included all things that were sour. (Lesson plan 3)

On the other hand in lesson plan 14 the accompanying text describes the discoveries of several scientists - but the focus is now on the results. Some information is given about the central experiments, but the text concentrates on defining concepts such as force and energy and describing the scientific principles such as conservation of energy.

Mayer also studied various phenomena, which involved heat and movement. In the first place, the author looked to see if he could establish a cause-effect relationship between heat and movement. This relationship admitted, the author announced that an experiment had been carried out: thanks to a forceful shaking of water contained in a recipient, this had raised the temperature around 12 to 13 degrees centigrade. In this case, Mayer admitted that heat comes from movement.(Lesson plan 14, emphasis original)

Many lesson plans include short descriptions of the scientists' background such as their birth date or where they have received education in science. Only one narrative (from lesson plan 25) in the material concentrates on biography of the scientist, with sole focus on personal history of the scientist in question.

Five lesson plans use narratives with several focuses. For example, in narrative from lesson plan 10 the personal history of Bunsen and Kirchoff was given in some detail:

Gustav Kirchoff was born in Königsberg, East Prussia, the son of Friedrich Kirchoff, a lawyer, and Johanna Henriette Wittke. He graduated from the Albertus University of Königsberg in 1847 where he attended the mathematico-physical seminar. He married Clara Richelot, the daughter of his mathematics professor Friedrich Julius Richelot. In the same year, they moved to Berlin, where he stayed until he received a professorship at Breslau. Kirchoff contributed to the fundamental understanding of electrical circuits using mathematical treatments. (Lesson plan 10)

At the same time the development in technology and content knowledge about absorption lines is accumulated: 
One afternoon in the summer of 1859 , Kirchoff looked at the interaction of incandescent light and the light of table salt burning in the flame of the Bunsen burner. Foucault had used sunlight. Here, the source of light was different. The observation was puzzling, however. The incandescent light was known to show a full, continuous spectrum. But when it passed through the sodium flame and then through the new spectroscope, a dark line appeared in the D position. 'There must be a fundamental story here', he thought. (Lesson plan 10)

\subsubsection{Number of Characters and Viewpoint Characters}

The majority of the narratives did not present scientists as working alone. In most of the lesson plans, several people are mentioned and given merit for their contribution to the scientific work (see Table 6). Most often the narrative focuses on one or two of them. There are huge differences on the detail of the description of the scientists' work. In some narratives scientists' work is marginalized and the discoveries just magically land on the scientist in a eureka-moment. Sometimes work done is described using basically just one word, such as "proved":

... His ideas about gas atoms were very different than what most scientists believed at that time. In fact, he proved the most widely believed property about gases to be wrong! His experiments with the gas called oxygen led to chemical names we use today. (Lesson plan 1)

Some of the descriptions of work are lengthier and included lots of details of the actual experiments or deductions.

A new experiment of this author is presented in June of the same year. In the experiment, a paddle-wheel immersed in water is used. When the paddles are put into movement, they push the water. The paddle-wheel is put into movement in the following way: the wheel axle is wrapped with a double thread, which is shared by two, diametrically placed pulleys. The falling movement of the two weights hung on the ends of the thread, make the paddle-wheel move.

The experiment consists of letting the weights fall and estimating the water temperature, before and after the fall: the movement of the weights happens 16 times before carrying out the final measurement of temperature. As the wheel moves according to the falling of the weights, Joule established a relationship between the mechanical power - given by the height of falling and the weight of the weights - and the heat developed - calculated by the variation in water temperature. (Lesson plan 14)

In the analysis of the narratives, a group of characters that are described in more detail and whose actions and reasons for actions are described in more detail than other characters' are considered viewpoint characters of narratives. Among the analyzed narratives there is only one narrative, (in lesson plan 17) which includes a clear viewpoint character. In a few other narratives intrinsic explanations regarding the emotions or values of the scientists are described. These descriptions were however too brief and shallow to allow the reader to understand and emphasize with the characters. Thus the characters are not regarded as true viewpoint characters. Below are two examples: 
What made Fritz Haber (1868-1934) take an interest in the synthesis of ammonia? At least in his Nobel-speach he told that he wanted to help the agriculture and develop fertilizers that can return nitrogen into the soil after harvest, since fertilizers can be made of ammonia. On the other hand it is certain that as a very patriotic man he also wanted to help Germany's industry of explosives. (...) (Lesson plan 25)

Robert fell in love with scientific instrumentation. During his early years of research, he became a great experimental worker and philosophical instrument maker. (Lesson plan 10)

The viewpoint character in lesson plan 17 has a central role in the narrative and his motives are discussed and justification was given to his decisions. The character, Mendeleev, is written in a fashion that allows reader to empathize with the character and to form an emotional connection with him.

\subsubsection{Conflicts in Narratives}

Conflict is one of the most common narrative structures of stories. In most narratives conflict is external rather than internal and includes a protagonist (hero) and an antagonist (villain) who opposes the protagonist. Such story structures are quite common also in science narratives, where the protagonist is usually a scientist, and other scientists or social institutions such as the Catholic Church serve the role of antagonist.

One of the things analyzed from the narratives was whether they included noticeable conflicts or controversies between rival theories, scientists or any other parties. Fourteen lesson plans include a narrative with such conflicts (see Table 6). In five of these lesson plans (lesson plans 8, 9, 14, 22 and 23) the narratives are clearly focused on one central conflict. For example in Lesson plan 22 Bohr and Lewis are introduced to the students using a play. In the play, Bohr and Lewis presented their differing theories of atom's structure and this controversy is used to inspire students' work on atom structure. Lesson plans 8 and 9 describe very long chains of events resulting in establishment of new theories.

\subsection{Examples of Historical Approach in Lesson Plans}

Lesson plans 2, 5 and 17 are used as examples of different uses of historical approach in the lesson plans analyzed. In Lesson plan 2, "Sucking Students into an Understanding of Air Pressure and Vacuums", the historical approach is used primarily for teaching science content using practical work. Lesson plan describes practical work students could conduct and states that students may "relate their experiences and ideas to the historical investigations". Similar approach where historical concepts are used to support students learning of scientific concepts is suggested in literature (e.g. Monk \& Osborne 1997, Rudge \& Howe 2009).

In lesson plan 2, teacher is not guided in the use of historical approach. The lesson plan includes detailed background of related historical events, presented in the form of a narrative, but it is unclear about the use of this narrative during the lesson. The lesson plan makes only vague suggestions on how to present any narrative for the students. Teacher is left unsure of 
should the historical narrative even be used with students, or is it meant only for teacher to recognize possible similarities between historical concepts and students' own conceptions.

Lesson plan 2 aims at teaching students about the empirical nature of science. Its NOS learning objective is stated as: "students will experience science as a way of understanding and explaining based on evidence and argument". However, the lesson plan gives very little attention on how to teach this NOS aspect or how to use history to support students learning of NOS or science, thus the approach is implicit (see Table 4).

Lesson plan 2 could be labeled as historically informed. As the practical work during the lesson is based on the historical narrative, the history has an integral role in the lesson plan, even if the use of history might not be clear to the students.

In Lesson plan 5, Perfumes: Chemistry in 17th-Century French Courts, historical approach is used to teach NOS. The lesson plan lists three "major NOS themes" to be discussed: "cultural context of science", "nature of investigation and discovery", and "science and the arts". It is suggested that the lesson could also be used to review principles of distillation at the end of unit of organic chemistry, or to teach "advanced concepts such as Dalton's law of partial pressure". The lesson also focuses on enhancing students' inquiry skills, as they design their own chemical products and report their findings.

The use of narrative in Lesson plan 5 could be described as comprehensive as all the activities on the lesson are closely connected to the narrative. The historical narrative is presented clearly at the beginning of the lesson plan and a character from the historical narrative is used in task in which designing a perfume. The lesson plan includes variety of follow up questions asking students to reflect on the NOS aspects to be learned. Historical background is used as basis for this reflection. For example, students are asked to explain distillation as a phenomenon by using Aristotle's four elements.

Compared to Lesson plan 2, Lesson plan 5 offers more support for teacher to discuss the NOS aspects of the lesson. However, the historical background in Lesson plan 5 is not extensive and teacher has to find out answers to many questions himself or herself. Also, there are no instructions on how the NOS discussion initiated by questions in the lesson plan should be guided. For example, instructions are given neither for explaining distillation using Aristotle's four elements nor how this issue should be discussed with students.

The lesson plan 17, A Puzzle with Many Pieces, is an example of finalized NOS teaching material. As written in the form of a story for student to read, it includes all the historical information teacher would need to use it. Lesson plan 17 includes only NOS learning objectives and it does not include information or exercises related to chemistry content knowledge. Lesson plan 17 discusses the widest variety of different NOS aspects of all the lesson plans analyzed (see Table 4).

The discussion of NOS is made reflective by using dialogue boxes, where students are asked to answer NOS questions. Other information boxes made the discussion explicit by offering answers and definitions of NOS issues to be learned. For example, the lesson plan explained the difference between laws and theories:

As you read the story of the development of the periodic table, note that scientific laws and theories are different forms of knowledge. Both make assertions about the natural world, and 
one never becomes the other. Scientific laws, like Mendeleev's Periodic Law, state invariable relationships in nature. Scientific theories explain those relationships. (Lesson plan 17)

The exercises are closely related to the narrative and thus the use of the narrative is comprehensive. The narrative has a strong focus on the development of the model and the scientific process but it also has one central character, Mendeleev, whose thinking and motivations are described in some detail. Lesson plan 17 is an example of lesson plan where both the amount of historical background and NOS-related exercises are in good balance and adequate for the use in teaching. The content of the narrative is also closely contacted to the exercises and NOS learning objectives.

\section{Discussion and Conclusions}

\subsection{Material Available for Teaching Nature of Science}

Historical approach has been suggested for teaching several NOS issues. Some examples of mentioned NOS aspects are epistemological nature of science (e.g. Irwin 2000, Monk \& Osborne 1997), social nature of science (e.g. Monk \& Osborne 1997, Stinner et al. 2003) and role of creativity (Irwin 2000). The lesson plans analyzed in this study offer several alternatives for discussing especially epistemological and empirical issues of science. Of analyzed lesson plans, $40 \%$ discuss how scientific knowledge changes, $36 \%$ discuss the scientific discovery, and $24 \%$ discuss the relationship between theories and empirical procedures. The limitations of scientific models are discussed in $20 \%$ of the lesson plans. The lesson plans also offer opportunities for discussing non-specific social and societal aspects of science, as $28 \%$ of the lesson plans discuss the role of collaboration in science and $16 \%$ discuss the influence of cultural context on scientific practice.

Some issues are discussed only in few lesson plans. These are characteristics of laws and theories, relationship between theories and interpretations, role of creativity, and instrumentation. If these issues are seen as important NOS issues to be taught, more curriculum material is needed for chemistry teachers. Some of the lesson plans could be adapted easily to discuss these issues. For example, the role of instruments in development of scientific theories could be discussed in Lesson plan 8 or in Lesson plan 16, which both present accounts about the difficulties related to the defining composition of compounds. In Lesson plan 16, scales are discussed in this context, but general discussion of the importance of instruments in chemistry is not given.

Historical experiments are suggested for teaching about the processes of science (Allchin 1999). Allowing students to replicate historical experiments may help them to understand the role of experiments in production of new knowledge (Höttecke 2000) and complementary experimentation allows them to learn about the nature of scientific inquiry and the limitations of modern science (Chang 2011). Lesson plans analyzed offer several alternatives for using history-inspired experiments to discuss empirical nature of science (see Table 5). 
Physical replications are used only in three lesson plans and complementary experimentation in one lesson plan. When designing further curriculum material, more attention should be paid on how different representations (i.e. historical or physical replications, complementary experiments, history-inspired experiments) support the NOS issues to be discussed during the lesson.

As replications of historical experiments may be used to discuss the role of experiments in science (Höttecke 2000), these types of experiments could also be used to discuss NOS issues such as instrumentation and creativity. For example, physical replications of experiments could be compared with historical experiments to discuss how the apparatus used may affect the observations obtained and even the research questions asked.

Further study is needed on what are the strengths of historical approach compared to the using contemporary science as context for case studies. Visiting research groups and interviewing scientists has been found suitable teaching model for discussing issues related to the social and societal aspects of science, role of instruments and scientific inquiry (Vesterinen \& Aksela 2009). In the lesson plans analyzed, the societal and social issues of science were discussed on a specific level only in few cases (e.g. discussion of the power plays inside science in Lesson plan 9). Discussing social and cultural NOS issues in a way that students can understand and relate to requires detailed and complex description of historical context (i.e. narrative). If these topics can be discussed using contemporary science, this approach may be easier for teachers to implement.

\subsection{Implications for Designing Historical Curriculum Material}

Historical context is used to discuss NOS on the level of context-specific issues. Rich historical context supported by historical case studies allows complex NOS discussion (Allchin 2011a). Most lesson plans covered only a limited number of rather specific NOS topics or issues (see Table 4). Based on the analysis of NOS objectives of the lesson plans, general NOS aspects listed in several NOS descriptions (e.g. Lederman et al. 2002) are not specific enough to be learning objectives of a single lesson. Rather than focusing on general NOS aspects, lesson plans designed for NOS instruction have to focus on a few relatively specific NOS issues.

Effective teaching of NOS content requires learning activities in which both teacher and students engage in explicit and reflective discussion of NOS (e.g. Abd-El-Khalick 2012, Lederman 2007). In many of the lesson plans analyzed the connection of the narrative and exercises were weak and narratives seemed to discuss NOS topics not mentioned in the exercises or learning objectives. This raises the question of whether this is efficient use of historical narratives, or is historical narrative even needed. Example of using narratives to support explicit NOS discussion is given in Lesson plan 17, where the discussion of the role of creativity in science was made possible by narrative that introduced the reader to the detailed problem-solving process needed in science. Lesson plan 17 also included exercises that discussed the NOS issues, making good use of the historical narrative. This use of comprehensive narratives, in which narrative is used as a context for lesson activities (see 
Subsection 4.3.1), increases the explicit discussion of NOS issues. ${ }^{10}$ Use of comprehensive narratives would also scaffold teachers who might not be that familiar with NOS or with the historical examples used in the lesson plans. To make sure that teacher understands the role and use of narratives in meeting the NOS learning objectives, the use of narratives should be made explicit in the lesson plans and connections between the narrative and NOS learning goals should be pointed out. Teacher is more likely to succeed in teaching the intended NOS issues, if there are clear connections between the exercises and the narrative.

Although comprehensive narratives can be used to explicitly discuss complex NOS issues (Allchin 2011a), increasing complexity also requires detailed narratives and more complex historical context. This takes up a sizable amount of the already limited resources in the classroom, and emphasizes the need to consider the content of the narrative presented for the students. It has been suggested that simplifying historical context supports teachers' use of historical approach (Rudge \& Howe 2009). Narratives can be made simpler for example by choosing the focus according to the NOS-issues to be discussed.

When social and societal aspects of NOS or science as a human endeavor are the topic to be addressed on the lesson, a very detailed picture may be needed by the students to gain understanding of the subtleties of NOS issues. In lesson plans analyzed, the discussion is taken to this subtle level only in few cases. Use of contemporary examples can be effective model for discussing social and societal issues (Vesterinen \& Aksela 2009). Contemporary approach may make it easier for students to empathize with the people participating in science and to understand the context where interactions take place. If historical approach is used, including view point characters into narrative may also aid mediating the motivations of scientists to the students. On the other hand, when the focus is on the epistemological issues (e.g. conceptual change), the limited time resources in the classroom should be saved by moving the focus of the narrative from the biographical side of the characters into the process of science. Further research is needed to understand the effect that changing the focus of the narrative has on the learning. For example many narratives in this study include biographical information unrelated to the exercises or learning goals of the lesson plan. If this biographical information does not support students learning of other topics, including it to the narrative only takes time and resources.

Suggested teaching models for conducting physical experiments are physical replications (Chang 2011, Höttecke 2000) and extensions of historical experiments (Chang 2011). Attention should be paid also on suitability of the experiments to schools and the relationship between experimentation and historical narrative (Metz \& Stinner 2006). According to results of this study, historical experiments and contemporary experimentation are mainly used to discuss the empirical issues (e.g. scientific discovery process, relationship between theoretical and empirical aspects, relationship between evidence and models).

Narratives usually include conflicts. Conflicts increase the narrative effect (discussion of narrative effect can be found in e.g. Norris et al. 2005) and for teaching purposes can also

\footnotetext{
${ }^{10}$ Comprehensive narrative is similar to the idea of history as unifying context in case study, suggested by Stinner and colleagues (2003). Also approaches used in MCSC and HIPST are described as case studies (Allchin 2011b, Höttecke \& Riess 2009) and aim at comprehensive use of narratives.
} 
support discussing NOS issues (e.g. scientific discovery process, change of scientific knowledge, development of models). In most of the narratives in this study a conflict was included and in many cases it was central to the presentation of the tentative nature of scientific knowledge and social nature of scientific work.

To summarize, when designing lesson where historical approach is used for teaching NOS, attention should be paid on four key issues:

- To have explicit discussion on the intended NOS issues, the objectives should concentrate on a few relatively specific NOS issues to be taught instead of general discussion of multiple NOS aspects.

- Comprehensive use of narratives is recommended. All parts of the lesson (e.g. exercises, laboratory work) should thus be connected to the narrative and curriculum material should include clear instructions on how to use the narrative in discussing the NOS issues with students.

- The use of narrative and historical experiments should be connected to the NOS issues chosen to be taught:

- Use view point characters and conflicts suits describing science as a human endeavor (e.g. creativity or collaboration between scientists).

$\circ$ Focus of the narrative on describing the scientific process suits discussion on the epistemological aspects of science (e.g. change of scientific knowledge or relationship between theoretical and empirical aspects of science).

- Use of historical experiments suits the discussion on the issues related to empirical aspects of NOS.

- To increase the narrative effect of the historical account, one should include at least one conflict in the narrative.

When building new curriculum material, one has to also acknowledge, that there is a difference between the intentions of curriculum material designers and the teachers' implementation in the classroom (see e.g. Hilderbrand 2007). All in all, very little is still known of how use of historical approach or the structure and features of the narrative (e.g. view point characters, foci of narratives) affect teachers practice and student learning (see also Klassen 2009). Authors are currently involved on an ongoing research project focused on pre-service chemistry teachers' ability to design and implement lessons utilizing historical approach. 


\section{References}

Abd-El-Khalick, F. (2012). Teaching With and About Nature of Science, and Science Teacher Knowledge Domains. Science \& Education, doi:10.1007/s11191-012-9520-2

Abd-El-Khalick, F. \& Ledermann, N. G. (2000a). The Influence of History of Science Courses on Students' Views of Nature of Science. Journal of Research in Science Teaching, 37(1), 10571095.

Abd-El-Khalick, F. \& Ledermann, N. G. (2000b). Improving Science Teachers' Conceptions of Nature of Science: a Critical Review of the Literature. International Journal of Science Education. 22(7), 665-701.

Allchin, D. (1999). History of Science - With Labs. Science \& Education, 8(6), 619-632.

Allchin, D. (2011a). Evaluating Knowledge of the Nature of (Whole) Science. Science Education, $95(3), 518-542$.

Allchin, D. (2011b). The Minnesota Case Study Collection: New Historical Inquiry Case Studies for Nature of Science Education. Science \& Education, 21(9), 1263-1281.

Chang, H. (2011). How Historical Experiments Can Improve Scientific Knowledge and Science Education: The Cases of Boiling Water and Electrochemistry. Science \& Education, 20(3-4), 317-341.

Clough, M. P. (2007). Teaching the Nature of Science to Secondary and Post-secondary Students: Questions Rather Than Tenets. The Pantaneto Forum, 25. Retrieved from http://www.pantaneto.co.uk/issue25/front25.htm.

Clough, M. P. (2011). The Story Behind the Science: Bringing Science and Scientists to Life in Post-Secondary Science Education. Science \& Education, 20(7-8), 701-717.

Ducheyne, S. (2012). The Cavendish Experiment as a Tool for Historical Understanding of Science. Science \& Education, 21(1), 87-108.

Garritz, A. (2013). Teaching the Philosophical Interpretations of Quantum Mechanics and Quantum Chemistry through Controversies. Science \& Education, 22(7), 1787-1807.

Henke, A., Höttecke, D., \& Riess, F. (2009). Case Studies for Teaching and Learning with History and Philosophy of Science. Paper presented at the Tenth International History, Philosophy, and Science Teaching Conference, South Bend, USA 2009, June 24-28, 2009. http://www3.nd.edu/ ihpst09/papers/Henke_MS.pdf . Accessed 24 April 2013.

Hildebrand, G. (2007). Diversity, Values and the Science Curriculum. In D. Corrigan, J. Dillon \& R. Gunstone (Eds.), The Re-Emergence of Values in Science Education (pp. 45-60). Rotterdam: Sense Publishers.

Hodson, D. 2008. Towards Scientific Literacy: A Teacher's Guide to the History, Philosophy and Sociology of Science (pp.149-172). Rotterdam, Netherlands: Sense Publishers.

Höttecke, D. (2000). How and what can We Learn from Replicating Historical Experiments? A Case Study. Science \& Education, 9(4), 342-362.

Höttecke, D. \& Riess, F. (2009). Developing and Implementing Case Studies for Teaching Science with the Help of History and Philosophy, Paper presented at the Tenth International History, Philosophy, and Science Teaching Conference, South Bend, USA 2009, June 24-28, 2009. http://www3.nd.edu/ ihpst09/papers/Hoettecke_Paper_IHPST09.pdf . Accessed 24 April 2013. 
Höttecke, D. \& Silva, C. C. (2011). Why Implementing History and Philosophy in School Science Education is a Challenge: an Analysis of Obstacles, Science \& Education, 20(3-4), 293-316.

Höttecke, D., Henke, A. \& Riess, F. (2012). Implementing History and Philosophy in Science Teaching: Strategies, Methods, Results and Experiences from the European HIPST Project. Science \& Education, 21(9), 1233-1261.

Irwin, A. R. (2000). Historical Case Studies: Teaching the Nature of Science in Context. Science Education, 84(1), 5-26.

Klassen, S. (2009). The Construction and Analysis of a Science Story: A Proposed Methodology. Science \& Education, 18(3-4), 401-423.

Kubli, F. (2001). Can the Theory of Narratives Help Science Teachers be Better Storytellers? Science \& Education, 10(6), 595-599.

Lederman, J. S., Lederman, N. G., Byoung, S. K. \& Eun, K. K. (2012). Teaching and Learning of Nature of Science and Scientific Inquiry: Building Capacity through Systematic ResearchBased Professional Development. In M. S. Khine (Ed.), Advances in Nature of Science Research, (pp. 125-152). Dordrecht, Netherlands: Springer.

Lederman, N. G. (1999). Teachers' Understanding of the Nature of Science and Classroom Practice: Factors that Facilitate or Impede the Relationship. Journal of Research in Science Teaching, 36(8), 916-929.

Lederman, N. G. (2007). Nature of Science: Past, Present, and Future. In S. K. Abell \& N. G. Lederman (Eds.), Handbook of Research on Science Education, (pp. 831-879). Mahwah, NJ: Lawrence Erlbaum Associates, Inc.

Lederman, N. G., Abd-El-Khalick, F., Bell, R. L. \& Schwartz, R. S. (2002). Views of Nature of Science Questionnaire: Toward Valid and Meaningful Assessment of Learners' Conceptions of Nature of Science. Journal of Research in Science Teaching, 39(6), 497-521.

Lin, C.-Y., Cheng, J.-H. \& Chang, W.-H. (2010). Making Science Vivid: Using a historical Episodes Map. International Journal of Science Education, 32(18), 2521-2531.

Lin, H.-S. \& Chen, C.-C. (2002). Promoting Preservice Chemistry Teachers' Understanding about the Nature of Science through History. Journal of Research in Science Teaching, 39(9), 773 792.

Matthews, M. R. (2012). Changing the Focus: From Nature of Science (NOS) to Features of Science (FOS). In M. S. Khine (Ed.), Advances in Nature of Science Research, (pp. 3-26). Dordrecht, Netherlands: Springer.

McComas, W. F. (2008). Seeking Historical Examples to Illustrate Key Aspects of the Nature of Science. Science \& Education, 17(2-3), 249-263.

de Mello Forato, T. C., de Andrade Martins, R. \& Pietrocola, M. (2012). History and Nature of Science in High School: Building Up Parameters to Guide Educational Materials and Strategies. Science \& Education, 21(5), 657-682.

Metz, D. \& Stinner, A. (2006). A Role for Historical Experiments: Capturing the Spirit of the Itinerant Lecturers of the 18th Century. Science \& Education, doi:10.1007/s11191-006-9016$\mathrm{z}$

Monk, M. \& Osborne, J. (1997). Placing the History and Philosophy of Science on the Curriculum: A Model for the Development of Pedagogy. Science Education, 81(4), 405-424.

Niaz, M. (2009). Progressive Transitions in Chemistry Teachers' Understanding of Nature of Science Based on Historical Controversies. Science \& Education, 18(1), 43-65. 
Niaz, M. (2010). Science Curriculum and Teacher Education: The role of Presuppositions, Contradictions, Controversies and Speculations vs. Kuhn's 'Normal Science'. Teaching and Teacher Education, 26(4), 891-899.

Niaz, M. \& Rodriguez, M. A. (2001). Do We Have to Introduce History and Philosophy of Science or is it Already 'Inside'Chemistry?. Chemical Education: Research and Practice in Europe 2(2), 159-164.

Norris, S. P., Guilbert, S. M., Smith, M. L., Hakimelahi, S. \& Phillips, L. M. (2005). A Theoretical Framework for Narrative Explanation in Science. Science Education, 89(4), 535-563.

Rudge, D. W. \& Howe, E. M. (2009). An Explicit and Reflective Approach to the Use of History to Promote Understanding of the Nature of Science. Science \& Education, 18(5), 561-580.

Stinner, A., McMillan, B. A., Metz, D., Jilek, J. M. \& Klassen, S. (2003). The Renewal of Case Studies in Science Education. Science \& Education, 12(7), 617-643.

Vesterinen, V.-M. \& Aksela, M. (2009). A Novel Course of Chemistry as a Scientific Discipline: How Do Prospective Teachers Perceive Nature of Chemistry Through Visits to Research Groups? Chemical Education Research and Practice, 10(2), 132-141.

Vesterinen, V.-M. \& Aksela, M. (2012). Design of Chemistry Teacher Education Course on Nature of Science. Science \& Education, doi:10.1007/s1119101295060.

Vesterinen, V.-M., Aksela, M. \& Lavonen, J. (2013). Quantitative Analysis of Representations of Nature of Science in Upper Secondary School Textbooks Using Framework of Analysis Based on Philosophy of Chemistry. Science \& Education, 22(7), 1839-1855.

Vesterinen, V.-M., Manassero-Mas, M. A. \& Vázques-Alonso, Á. (in press). History and Philosophy of Science and Science, Technology and Society Traditions in Science Education: Their Continuities and Discontinuities. In M. R. Matthews (Ed.), International Handbook of Research in History, Philosophy and Science Teaching. Dordrecht, Netherlands: Springer.

Wandersee, J. H. (1990). On the Value and Use of the History of Science in Teaching Today's Science: Constructing Historical Vignettes, in D. E. Herget (Ed.), More History and Philosophy of Science in Science Teaching (pp. 278-283). Florida State University, Tallahassee, FL.

Wandersee, J. H. \& Baudoin Griffard, P. (2002). The History of Chemistry: Potential and Actual Contributions to Chemical Education, in J. K. Gilbert, O. De Jong, R. Justi, D. F. Treagust \& J. H. Van Driel (Eds.), Chemical Education: Towards Research-Based Practice (pp. 29-46). Kluwer Academic Publishers, Dordrecht, NL. 